\title{
ABSTRAK \\ PENGARUH KOMPENSASI DAN MOTIVASI KERJA TERHADAP KINERJA KARYAWAN PRODUKSI PUPUK DI KARAWANG
}

\author{
Oleh : \\ Sungkono 1 \\ Aji Tuhagana ${ }^{2}$ \\ Email: sungkono@ubpkarawang.ac.id \\ aji.tuhagana@ubpkarawang.ac.id
}

Program Studi Manajemen FBIS Universitas Buana Perjuangan Karawang

Kinerja adalah tentang melakukan pekerjaan dan hasil kerja yang dicapai dari pekerjaan tersebut. Kinerja karyawan dapat dipengaruhi oleh kompensasi dan motivasi kerja. Jika kompensasi terpenuhi maka motivasi kerja karyawan tinggi dan kinerja karyawan akan meningkat.

Penelitian ini bertujuan untuk memperoleh bukti- bukti empirik dan menemukan kejelasan fenomena serta kesimpulan tentang pengaruh kedua variabel terhadap kinerja karyawan. Karya ilmiah ini diharapkan dapat memberikan sumbangan bagi pengembangan ilmu manajemen.

Metode penelitian ini deskriptif dan verifikatif, yaitu mengumpulkan, menyajikan, menganalisis dan melakukan pengujian hipotesis, serta membuat kesimpulan dan saran. Sampel dikumpulkan dengan menggunakan metode Sample Random Sampling dengan jumlah sampel sebanyak 124 responden dari populasi 180 orang. Teknik analisis digunakan dengan teknik analisis rentang skala dan analisis jalur dengan bantuan Method Of Successive Interval (MSI), program komputer microsoft Excel 2016, dan SPSS versi 20.

Hasil penelitian diperoleh bahwa kompensasi berdasarkan hasil analisis dari indikator menunjukan skor rata- rata sebesar 494 yang berada pada garis rentang skala baik, motivasi kerja berdasarkan hasil analisis dari indikator menunjukan skor rata- rata sebesar 500 yang berada pada garis rentang skala baik, kinerja karyawan pada berdasarkan hasil analisis dari indikator menunjukan skor rata- rata sebesar 508 yang berada pada garis rentang skala baik. Terdapat hubungan yang sedang antara kompensasi dan motivasi kerja, dari nilai analisis korelasi sebesar 0,462. Terdapat pengaruh kompensasi secara parsial terhadap kinerja karyawan sebesar 0,541 atau $54,1 \%$, dan terdapat pengaruh motivasi kerja secara parsial terhadap kinerja karyawan sebesar 0,094 atau 09,4\%. Pengaruh kompensasi dan motivasi kerja secara simultan terhadap kinerja karyawan sebesar 0,635 atau $63,5 \%$ sedangkan sisanya 0,365 atau $36,5 \%$ merupakan kontribusi variabel lain $(\varepsilon)$ yang tidak diteliti.

Kata Kunci : Kompensasi, Motivasi Kerja, Kinerja Karyawan. 


\section{ABSTRACT \\ THE EFFECT OF WORK COMPENSATION AND MOTIVATION ON THE PERFORMANCE OF EMPLOYEES OF FERTILIZER PRODUCTION IN KARAWANG}

By:

\section{Sungkono 1}

Aji Tuhagana ${ }^{2}$

Email: sungkono@ubpkarawang.ac.id

aji.tuhagana@ubpkarawang.ac.id

The performance is about perform work and a result of working achieved from the job.Of employee performance can be influenced by the compensation and motivation of work. If compensation met then motivation high and employees work of employee performance will increas.

This research aims to obtain o empirical evidence and found clarity the phenomenon and conclusions about the influence of both variables on the performance of employees. A thesis is expected to contribute to the development of management sciences.

A method of this research and verifikatif descriptive, namely in collecting, presents, to analyse and do the testing of hypotheses, as well as making conclusion and recommendations. Sample gathered by uses the method sample random sampling to the total number of samples from 124 respondents of the population 180 people. Analysis techniques used with analysis techniques range the scale and with the help of the analysis method of successive of the intervals (msi), a computer program microsoft excel 2016, and spss version 20 .

The research results obtained that compensation based on the analysis of the indicators showed average score of 494 in line the, fine scales the work based on the results of the analysis of the indicators showed average score of 500 in line the, fine scales employee performance on the basis of the analysis of the indicators showed average score of 508 in line the fine scales. There are the relationships that are between compensation and motivation of work, of the value of correlation analysis as much as 0,462.Compensation is in full on the performance of employees as much as 0,541 or 54,1\%, and there are partial motivational influence on the performance of a work as employees as much as 0,094 or 09,4\%.The influence of compensation and motivation of a work as simultaneous on the performance of employees as much as 0,635 or $64.6 \%$ while the rest 0,365 or $36,5 \%$ is the contribution of another variable $(\varepsilon)$ that does not be researched.

Keywords: Compensation, Work Motivation, Employee Performance. 


\section{PENDAHULUAN}

Perkembangan perusahaan di indonesia kini dituntut untuk peka terhadap peraturan normatif yang telah ditetapkan pemerintah sebagaimana menjadi landasan aturan pemerintah terhadap prusahaan untuk menjamin keamanan dan kenyamanan karyawan dalam bekerja sehingga kinerja karyawan akan meningkat. Menurut Undang- Undang ketenagakerjaan no 13 tahun 2003 pasal 108-115 peraturan perusahaan merupakan unsur yang paling penting bagi stabilitas usaha dan pembinaan karyawan. Pengusaha yang mempekerjakan pekerja/buruh sekurang-kurangnya 10 orang wajib membuat peraturan perusahaan yang mulai berlaku setelah disahkan oleh menteri. Fungsi peraturan perusahaan dibuat untuk melindungi hak dan kewajiban perusahaan diantaranya pengusaha dan karyawan memiliki kepentingan masing- masing. Pengusaha membutuhkan karyawan untuk membantu kinerja perusahaan, karyawan menerima gaji sebagai haknya dari kinerjanya. Peraturan perusahaan menjamin kinerja karyawan, setiap karyawan menjalankan tugasnya yang sesuai dengan job dekarya ilmiah, berguna untuk mengatur keharmonisan perusahaan. Dengan adanya peraturan perusahaan maka akan terhindar dari berbagai macam gangguan, setiap ada pelanggaran akan ditindak tegas jika perlu diadakannya sangsi sesuai dengan tingkat kesalahannya. Dengan adanya peraturan perusahaan akan mengurangi masalah keharmonisan dalam perusahaan dan penurunan kinerja pada karyawan.

Berikut grafik perkembangan jumlah pegawai pupuk kujang dalam tiga tahun terakhir dapat dilihat dibawah ini :

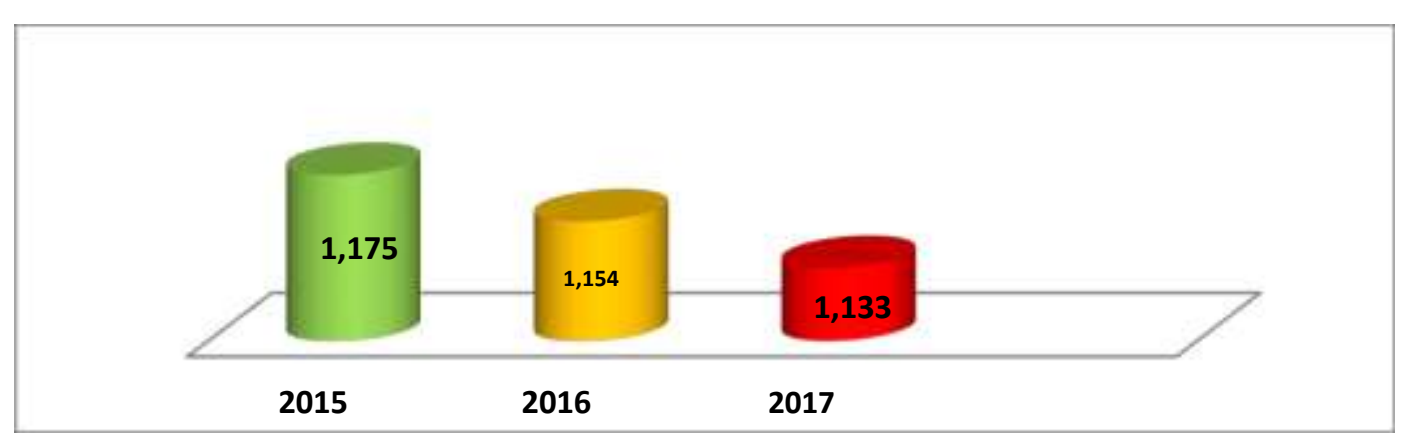

Gambar 1.1: Jumlah pegawai PT Pupuk Di Karawang 2015-2017

Sumber : Laporan tahunan 2017 PT. Pupuk Kujang 
Berdasarkan tabel diatas pada akhir tahun 2017, jumlah karyawan PT Pupuk Di Karawang sebanyak 1.133 karyawan, terdiri atas karyawan tetap 1.122 karyawan, karyawan trainee sebanyak 9 orang dan karyawan honorer sebanyak 2 orang dibandingkan dengan tahun 2016 dikarenakan banyaknya karyawan yang keluar pada tahun 2017 sebanyak 41 orang dengan karyawan pensiun sebanyak 22 orang, mengundurkan diri sebanyak 5 orang dan mutasi ke pupuk indonesia sebanyak 14 orang. Melihat perpindahan karyawan yang terjadi pada PT Pupuk Di Karawang ini akibat dari menurunnya tingkat motivasi kerja karyawan terhadap perusahaan, tingkat perpindahan karyawan yang tinggi akan mengganggu jalannya aktifitas kerja, sebab di dalam suatu perusahaan setiap karyawan menempati posisinya dan mengerjakan pekerjaannya masing- masing sehingga posisi yang kosong akan memperlambat jalannnya pelaksanaan pekerjaan.

Motivasi kerja yang tinggi tidak akan tumbuh begitu saja apabila kondisi dan faktor yang menumbuhkan motivasi karyawan tidak ikut mendukungnya. Apabila suatu perusahaan mengalami keadaan dimana motivasi kerja karyawan rendah dan kinerja karyawan menurun, sudah sewajarnya jika perusahaan mencari akar permasalahan mengenai faktor- faktor yang menjadi penyebab permasalahan itu muncul pada karyawan, seperti dengan melihat bagaimana kesejahteraan karyawan karena pemberian kesejahteraan akan menciptakan ketenangan, semangat kerja, dedikasi, disiplin dan sikap loyal karawan terhadap perusahaan sehingga labour turnover relative rendah.

Dari fenomena yang terjadi dapat disimpulkan bahwa perlunya perusahaan memperhatikan kesejahteraan karyawan guna meningkatkan motivasi kerja karyawan yang akan berpengaruh terhadap tinggi rendahnya kinerja karyawan sehingga karyawan akan memberikan kontribusi yang maksimal kepada perusahaan. Dalam mengukur kesejahteraan karyawan salah satunya dengan pemberian kompensasi yang sesuai, apabila dalam pemberian kompensasi yang berupa finansial maupun nonfinansial tidak terpenuhi secara tepat, maka perusahaan bisa kehilangan karyawannya dan harus mengeluarkan biaya untuk menarik, menyeleksi, melatih dan mengembangkan penggantinya. Bahkan karyawan juga akan merasa tidak puas terhadap perusahaan sehingga kualitas kinerja karyawan akan menurun. Oleh karena itu pemberian kompensasi yang 
sesuai sangat berpengaruh besar tehadap kualitas kerja karyawan, dimana ukuran sesuai yang dimaksud adalah kompensasi yang dapat meningkatkan kinerja dan kepuasan kerja karyawan. Pemberian kompensasi bertujuan untuk memotivasi karyawan agar lebih giat bekerja, disiplin saat bekerja, membantu menciptakan kesadaran bersama diantara para karyawan, mampu mengerjakan segala sesuatu yang dibutuhkan perusahaan, memperoleh personil yang bermutu, mencegah keluarnya karyawan yang ada, menjamin keadilan dan penghargaan terhadap karyawan.

Setiap karyawan belum tentu bersedia untuk mengerahkan semua kemampuan yang dimilikinya secara optimal, sehingga masih diperlukan adanya dorongan dari pihak luar. Untuk itu agar bisa menumbuhkan motivasi kerja yang insentif antara karyawan dengan pimpinan maupun antar semua karyawan dibutuhkan suatu komunikasi agar menciptakan suasana kerja yang kondusif terhadap lingkungan kerja perusahaan, sehingga karyawan akan merasa nyaman dan mampu bekerja dengan baik dan bermanfaat bagi perusahaan.

Apabila terjadi penurunan dalam potensi karyawan atau terdapat penyimpangan pada karyawan maka perusahaan harus lebih selektif dalam menilai kinerja karyawan sehingga kinerja yang diharapkan oleh perusahaan bertambah baik dan sesuai dengan yang dibutuhkan oleh perusahaan untuk mencapai tujuan perusahaan lebih maksimal lagi. Masalah- masalah yang terjadi diatas bisa disebabkan oleh beberapa faktor ada banyak sekali faktor- faktor yang menyebabkan penurunan motivasi pada karyawan yang menyebabkan kinerja karyawan kurang stabil diantaranya yaitu kebutuhan- kebutuhan karyawan yang tidak terpenuhi, masalah pada kompensasi, masalah pada kenyamanan bekerja, masalah pada loyalitas karyawan terhadap perusahaan, masalah kepuasan kerja karyawan dan masih banyak lagi.

Berdasarkan latar belakang diatas dengan fenomena dan permasalah yang ada pada perusahaan mengenai kompensasi dan motivasi kerja yang berpengaruh terhadap kinerja karyawan di PT Pupuk Di Karawang, penulis tertarik untuk meneliti mengenai variabel kompensasi dan motivasi kerja terhadap kinerja karyawan di PT Pupuk Di Karawang karena melihat fenomena di sekitarnya 
dimana terdapat permasalahan- permasalahan terkait dengan variabel yang penulis teliti. Berdasarkan uraian diatas maka penulis tertarik mengadakan penelitian yang kemudian akan dituangkan dan diolah dalam bentuk tulisan ilmiah ini.

\section{TINJAUAN PUSTAKA}

Dalam penelitian ini peneliti akan membahas pustaka yang berhubungan dengan topik dan masalah penelitian, Pustaka yang akan dibahas yaitu Kompensasi, Motivasi kerja dan Kinerja karyawan. Oleh karena itu peneliti menggunakan beberapa sumber yang relevan yang berhubungan dengan masalah yang akan diteliti.

\section{Manajemen Sumber Daya Manusia}

Sumber Daya Manusia merupakan kekuatan daya pikir dan berkarya manusia yang masih tersimpan dalam diri, yang perlu digali, dibina, dikembangkan untuk dimanfaatkan sebaik-baiknya bagi kesejahteraan kehidupan manusia. Sdm merupakan kemampuan potensial yang dimiliki manusia yang terdiri dari kemampuan berikir, berkomunikasi, bertindak, dan bermoral untuk melaksanakan suatu kegiatan (bersifat Teknis maupun manajerial). Kemampuan yang dimiliki tersebut akan dapat mempengaruhi sikap dan perilaku manusia dalam mencapai tujuan hidup, baik individual maupun bersama. Sdm adalah semua potensi yang dimiliki oleh manusia yang disumbangkan atau diberikan kepada masyarakat untuk menghasilkan barang atau jasa.

Menurut Sedarmayanti (2017:03) manajemen Sumber Daya Manusia (MSDM) merupakan suatu proses pemanfaatan Sdm secara efektif dan efisien melalui kegiatan perencanaan, penggerakan, dan pengendalian semua nilai yang menjadi kekuatan manusia untuk mencaai tujuan.

Berdasarkan definisi diatas dapat disimpulkan bahwa manajemen sumber daya manusia adalah proses penggabungan fungsi manajmeen meliputi perencanaan, penggerakan, dan pengendalian, dan fungsi sdm meliputi perekrutan, penyaringan, pelatihan, pengimbalan, dan penilaian. untuk mencapai suatu tujuan individu dan organisasi. 
Manajemen Sumber Daya Manusia (MSDM) merupakan suatu pendekatan dalam mengelola masalah manusia berdasarkan tiga prinsip dasar, yaitu :

1. Sumber daya manusia adalah harta atau aset paling berharga dan penting yang dimiliki organisasi karena keberhasilan organisasi sangat ditentukan oleh unsur manusia.

2. Keberhasilan sangat mungkin dicapai, jika kebijakan prosedur dan peraturan yang berkaitan manusia dari perusahaan saling berhubungan dan menguntunmgkan semua pihak yang terlibat dalam perusahaan.

3. Budaya dan nilai organisasi perusahaan serta perilaku manajerial yang berasal dari budaya tersebut akan memberi pengaruh besar terhadap pencapaian hasil terbaik.

\section{Kompensasi}

Kompensasi merupakan salah satu fungsi yang penting dalam manajemen sumber daya manusia. Kasus yang terjadi dalam hubungan kerja mengandung masalah kompensasi dan berbagai segi yang terkait, seperti tunjanga, kenaikan kompensasi, struktur kompensasi, dan skala kompensasi. Sistem kompensasi membantu dalam memberi penguatan terhadap nilai- nilai kunci organisasi serta memfasilitasi pencapaian tujuan organisasi. Kompensasi dimaksudkan sebagai balas jasa (reward) perusahaan terhadap pengorbanan waktu, tenaga dan pikiran yang telah diberikan karyawan terhadap perusahaan.

Beberapa pengertian kompensasi yang dikemukakan oleh para ahli, antara lain :

Menurut Arif Yusuf Hamali (2018:78) bahwa "kompensasi adalah balas jasa perusahaan terhadap pengorbanan waktu, tenaga, dan pikiran yang telah dieberikan karyawan kepada perusahaan" .

Menurut Sedarmayanti (2017:173) bahwa "kompensasi adalah segala sesuatu yang diterima oleh pegawai sebagai balas jasa atas kontribusinya kepada perusahaan/organisasi. berbentuk uang, barang langsung atau tidak langsung yang diterima karyawan sebagai imbalan atas jasa yang diberikan keada perusahan".

Berdasarkan definisi para ahli diatas dapat disimpulkan Kompensasi merupakan unsur biaya yang dikeluarkan perusahaan sebagai balas jasa pada 
karyawan atas pengorbanan sumberdaya (waktu, tenaga, dan pikiran) serta kompetensi (pengetahuan, keahlian, dan kemampuan) yang telah mereka curahkan selama periode waktu tertentu sebagai sumbangan pada pencapaian tujuan organisasi dan diterimakan karyawan sebagai pendapatan yang merupakan bagian dari hubungan kepegawaian yang dikemas dalam suatu sistem imbalan jasa.

\section{Motivasi Kerja}

Motivasi kerja adalah sesuatu yang menimbulkan dorongan/semangat kerja/pendorong semangat kerja. Istilah motivasi (motivation) berasal dari bahasa latin yaitu "movere" yang artinya "menggerakan" (to move).

Motivasi mempersoalkan bagaimana cara mendorong semangat kerja karyawan, agar mereka mau bekerja keras dengan memberikan semua pengetahuan, keterampilan dan tenaga untuk mewujudkan pencapaian tujuan perusahaan.

Menurut Sedarmayanti (2017:154) Motivasi adalah kekuatan yang mendorong seseorang untuk melakukan suatu tindakan atau tidak yang pada hakikatnya ada secara internal dan eksternal positif ataupun negatif untuk mengarahkannya sangat bergtantung pada ketangguhan pimpinan.

Kondalkar dalam Arif Yusuf Hamali (2018:131) Mendefinisikan motivasi sebagai hasrat dalam yang membakat yang disebabkan oleh kebutuhan, keinginana, dan kemauan yang mendorong seorang individu untuk menggunakan energi fisik dan mentalnya demi tercapainya tujuan- tujuan yang diinginkan.

Berdasarkan definisi yang dikemukakan oleh para ahli maka dapat disimpulkan bahwa Motivasi kerja adalah dorongan dari internal maupun dari eksternal untum melakukan suatu tindakan guna mencapai suatu tujuan.

\section{Teori Motivasi Kerja}

Menurut Sedarmayanti (2017:155) terdapat beberapa teori- teori motivasi yag dikenal yaitu sebagai berikut :

1. Teori Abraham H. Maslow

Abraham Maslow yang terkenal dengan teori jenjang kebutuhan mengungkapkan kebutuhan manusia dapat diaktegorikan dalam lima jenjang 
dari yang paling rendah hingga jenjang yang paling tinggi. Jenjang kebutuhan menurut Maslow digambarkan sebagai berikut :

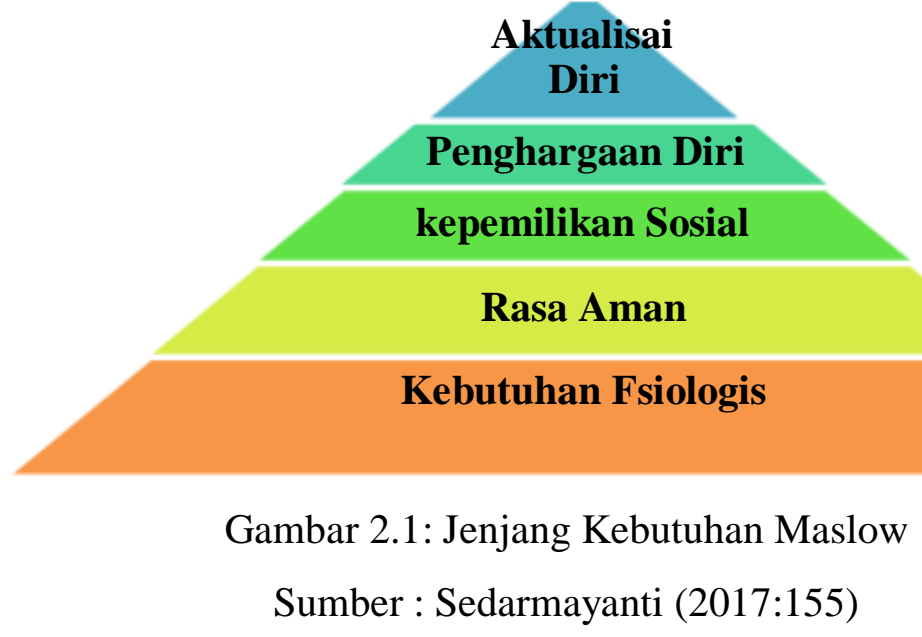

1. Aktualisasi Diri

Kebutuhan : menggunakan kemampuan, keterampilan, potensi, kebutuhan berpendapat dengan mengemukakan ide, memberi penilaian, kritik terhadap sesuatu.

2. Penghargaan Diri

Kebutuhan : harga diri, dihormati, dihargai oranglain.

3. Kepemilikan Sosial

Kebutuhan : rasa memiliki, diterima kelompok, berafiliasi, berinteraksi dan untuk mencintai dan dicintai.

4. Rasa Aman

Kebutuhan : rasa aman, perlindungan dari ancaman bahaya, pertentangan, dan lingkungan hidup.

5. Kebutuhan Fsiologis

Kebutuhan : fsiologis, makan, minum, perlindungan fisik, dan seksual.

Terlepas dari kritik yang ada, teori jenjang kebutuhan dari maslow memiliki impilkasi praktis yang berguna bagi pimpinan. Teori ini menawarkan pola konsepsi untuk memahami dan menangani masalah motivasi orang ditempat kerja. Pimpinan organisasi yang memahami pola kebutuhan sifatnya akan dapat membantu mereka melibatkan diri dalam aktivitas dan menyediakan lingkungan kerja yang dapat memuaskan kebutuhan mereka. 


\section{Kinerja}

Konsep kinerja atau prestasi kerja merupakan singkatan dari kenetika energi kerja yang padanannya dalam bahasa inggris adalah performance (Wirawan, 2012:5). Istilah performance sering di bahasa indonesiakan sebagai performa, atau dikenal juga dengan istilah kinerja. Kinerja merupakan prilaku nyata yang ditampilkan setiap orang sebagai prestasi kerja yang dihasilkan oleh karyawan sesuai dengan perannya. Kinerja karyawan merupakan hal yang sangat penting dalam upaya perusahaan untuk mencapai tujuannya.

Kinerja merupakan suatu fungsi dari motivasi dan kemampuan untuk menyelesaikan tugas atau pekerjaan seseorang, yang sepatutnya memiliki derajat kesediaan dan kemampuan tertentu, kesediaan dan keterampilan seseorang tidaklah cukup efektif untuk mengerjakan sesuatu tanpa memahami tentang apa yang akan dikerjakan dan bagaimana mengerjakannya.

Menurut mangkunegara (2001:67) dalam Yohanes Susanto (2017: 51) mengatakan kinerja adalah hasil kerja secara kualitas dan kuantitas yang dicapai karyawan dalam melaksanakan tugasnya sesuai dengan tanggung jawab yang diberikan kepadanya.

Sedangkan menurut Soelaiman Sukmalana (2007:167) dalam Yohanes Susanto (2017: 51) mengatakan kinerja adalah sebagai suatu yang dikerjakan dan dikaitkan dalam bentuk produk maupun jasa dalam satu periode tertentu dan ukuran tertentu oleh seseorang atau kelompok yang didasarkan pada kecakapan, kemampuan, pengetahuan maupun pengalaman.

Menurut Wibowo (2010:7) kinerja adalah tentang melakukan pekerjaan dan hasil kerja yang dicapai dari pekerjaan tersebut.

Berdasarkan definisi yang dikemukakan oleh para ahli maka dapat disimpulkan bahwa kinerja adalah suatu hasil kerja yang dicapai oleh seseorang pegawai sesuai dengan standar dan kriteria yang telah ditetapkan dalam kurun waktu tertentu.

Penulis menjabarkan kerangka pemikiran yang akan dijadikan pegangan dalam penelitian ini sebagai berikut : 


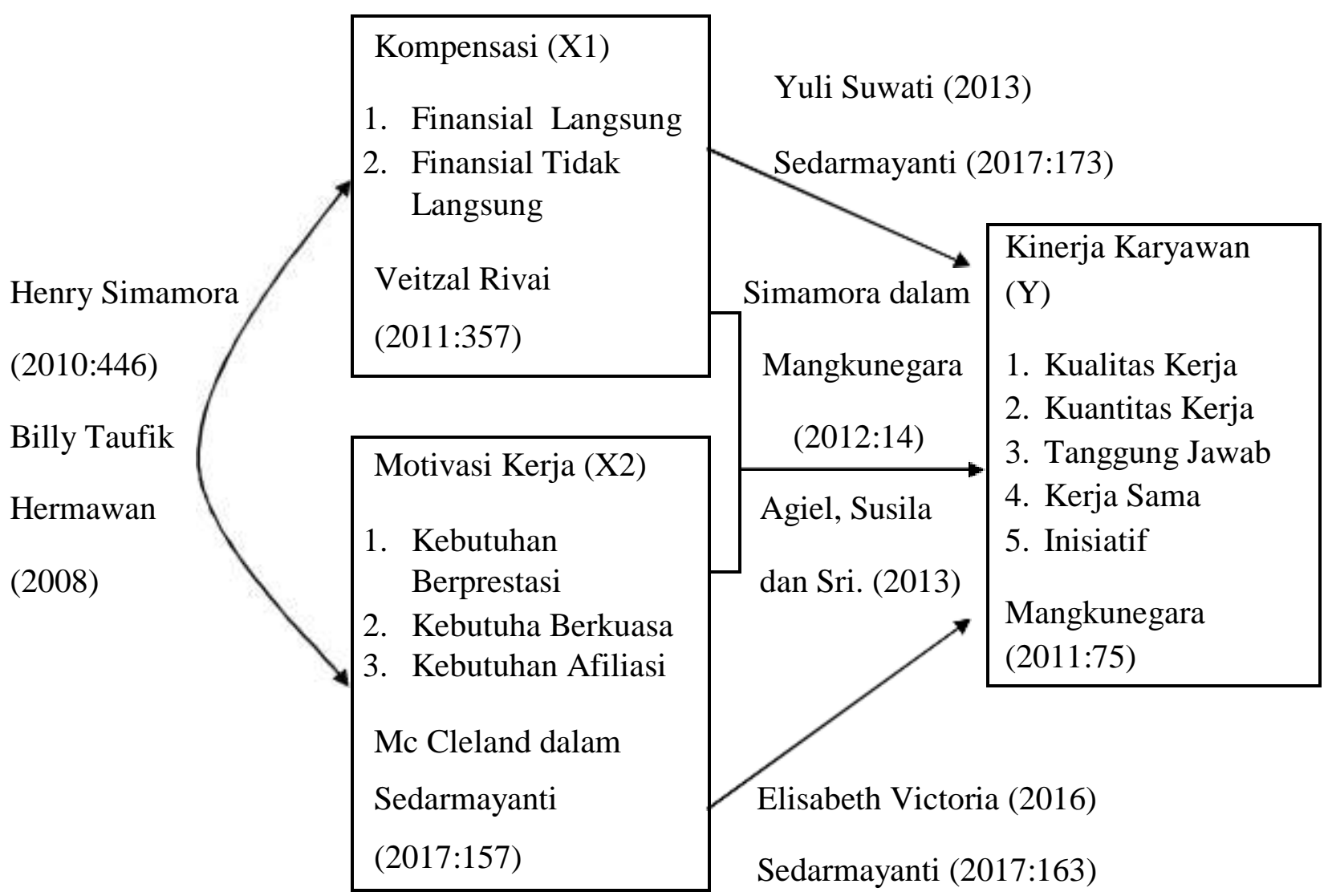

Gambar 2.2 : Paradigma Penelitian

Sumber : Data diolah penulis, 2019

\section{Hipotesis Penelitian}

1. Terdapat Korelasi antara kompensasi dengan motivasi kerja karyawan Kantor Gedung Pusat Administrasi PT Pupuk Di Karawang.

2. Terdapat pengaruh parsial antara kompensasi dan motivasi kerja terhadap kinerja karyawan Kantor Gedung Pusat Administrasi PT Pupuk Di Karawang.

3. Terdapat pengaruh simultan kompensasi dan motivasi kerja terhada kinerja karyawan Kantor Gedung Pusat Administrasi PT Pupuk Di Karawang.

\section{METODE PENELITIAN}


Penelitian ini akan melihat pengaruh kompensasi dan motivasi terhadap kinerja PT Pupuk Di Karawang, Untuk memperoleh data. peneliti menggunakan metode descriptive survey dan explanatory survey. Untuk menggambarkan mengenai keadaan masing- masing variabel yaitu variabel kompensasi, variabel motivasi kerja dan variabel kinerja. Metode ini diguakan untuk menggambarkan asosiasi, hubungan ataupun pengaruh variabel kompensasi dan motivasi kerja terhadap kinerja karyawan. Dengan metode ini penulis bermaksud mengumpulkan historis dan mengamati secara seksama mengenai aspek-aspek tertentu yang berkaitan dengan masalah yang sedang diteliti oleh penulis sehingga akan memperoleh data-data yang dapat mendukung penyusunan laporan penelitian.

Sifat penelitian yang digunakan dalam penelitian ini yaitu adalah deskriftif dan verifikatif. Penelitian deskriftif merupakan penelitian yang dilakukan untuk mengetahui nilai variabel mandiri, baik satu variabel atau lebih (independen) tanpa membuat perbandingan atau menghubungkan dengan variabel lain. Dengan menggunakan metode deskriptif, maka akan diperoleh :

1. Gambaran Tingkat Kompensasi Karyawan PT Pupuk Di Karawang.

2. Gambaran Tingkat Motivasi Kerja Karyawan PT Pupuk Di Karawang.

3. Gambaran Tingkat Kinerja Karyawan PT Pupuk Di Karawang.

Sedangkan Penelitian Verifikatif adalah penelitian yang pada dasarnya ingin menguji kebenaran melalui pengumpulan data di lapangan. Penelitian ini digunakan untuk menguji kebenaran dari hipotesis melalui pengumpulan data dilapangan. Penelitian Verifikatif bertujuan untuk mengetahui sejauh mana pengaruh kompensasi dan motivasi kerja terhadap kinerja Karyawan PT Pupuk Di Karawang. 


\section{Sumber dan Teknik Pengumpulan Data/Informasi}

Jenis data yang digunakan pada penelitian ini terdapat dua jenis data yaitu data primer dan data sekunder sebagai berikut :

\section{Data Primer}

Data primer adalah data yang berasal dari sumber asli ataupun pertama. Dalam penelitian ini data yang diperoleh berasal dari hasil wawancara dengan pihak yang bersangkutan dengan variabel penelitian dan hasil penyebaran kuesioner kepada karyawan PT Pupuk Di Karawang.

\section{Data Sekunder}

Data sekunder merupakan data yang berasal dari sumber kedua yang dapat diperoleh melalui buku- buku, jurnal dan artikel yang didapat dari website yang berkaitan dengan penelitian ini. Atau data yang berasal dariorang- orang kedua atau bukan data yang datang secara langsung. Data ini mendukung pembahasan dan penelitian, untuk itu beberapa sumber buku atau data yang diperoleh akan membantu dan mengkaji secara kritis penelitian tersebut. Untuk memperoleh dataini peneliti mengambil sejumlah buku- buku, jurnal, website dan contoh penelitian sebelumnyayang berkaita dengan penelitian ini.

Sumber data penelitian yang digunakan dalam penelitian ini adalah penelitian kuantitatif dimana penelitian ini dengan menganalisa menggunakan angka- angka rumus atau model berdasarkan tujuan penelitian. Penelitian kuantitatif ini dengan menggunakan pendekatan eksplanatory research yaitu pendekatan penjelasan yang menguji dua hipotesis yang menyatakan hubungan sebab akibat. Diantaranya dengan menggunakan dua sumber data sebagai berikut :

\section{Data Internal}

Data internal adalah data yang diambil dari dalam tempat dilakukannya penelitian

\section{Data Eksternal}

Data eksternal adalah data yang diambil dari luar tempat dilakukannya penelitian data tersebut sebagai data pendukung yang dalam penelitian ini data diambil dari kuesioner yang disebarkan kepada responden yang mewakili pendapat dan populasi yang ada. 
Teknik pengumpulan data adalah teknik atau cara- cara yang dapat digunakan oleh peneliti untuk pengumpulan data, karena tujuan utama dari penelitian adalah mendapatkan data. Untuk mengetahui gambaran prihal masalah yang sebenarnya. Oleh karena itu proses pengumpulan data dalam penelitian ini melalui beberapa tahapan penelitian yaitu :

\section{Studi Kepustakaan}

Studi kepustakaan digunakan untuk mendapatkan informasi yang relevan dengan topik atau masalah yang menjadi objek penelitian. Informasi tersebut dapat diperoleh dari sumber yang relevan seperti buku- buku, jurnal, penelitian terdahulu yang berkaitan dengan penelitian. Hal ini dilakukan untuk mendapatkan tambahan pengetahuan sesuai dengan masalah yang sedang diabahas.

\section{Studi Lapangan}

Studi lapangan digunkan untuk mendapatkan informasi langsung dari objek yang bersangkutan dengan melalui observasi, wawancara, dan penyebaran kuesioner kepada karyaan.

\section{Teknik Skala}

Dalam penelitian ini penulis menggunakan skala likert, Menurut Sugiyono (2012:93) skala likert digunakan untuk mengukur sikap, pendapat dan persepsi sseorang atau sekelompok orang tentang fenomena sosial. Variabel yang akan diukur menjadi indikator dan akan dijadikan sbagai tolak ukur menyusun itemitem berupa pertanyaan atau pernyataan.jawaban setiap item skala likert yang digunakan mempunyai grdasi dari sangat positif sampai negatif. Seperti tabel sebagai berikut :

Tabel 3.4

Skala Likert

\begin{tabular}{|c|c|c|c|}
\hline Kompensasi & Motivasi Kerja & Kinerja & Bobot Skor \\
\hline Sangat Baik & Sangat Baik & Sangat Baik & 5 \\
\hline Baik & Baik & Baik & 4 \\
\hline Cukup Baik & Cukup Baik & Cukup Baik & 3 \\
\hline Tidak Baik & Tidak Baik & Tidak Baik & 2 \\
\hline Sangat Tidak Baik & Sangat Tidak Baik & Sangat Tidak Baik & 1 \\
\hline
\end{tabular}

Sumber : Sugiyono (2012:93) 


\section{Transformasi Data Berskala Ordinal Menjadi Interval}

Trasformasi data yaitu merubah bentuk data dari asli kebentuk lain tanpa merubah data aslinya. Pada pendekatan analisis jalur (analysis path) seringkai mennggunakan tipe data ordinal. Tipe data tersebut merubah yang sebelumnya berasal daru suatu konsep yang diubah bentuknya sehingga dapat diukur. Analisis jalur membutuhkan perhitungan yang sistematis didalamnya. Oleh karena itu skala yang dibutuhkan harus berskala interval jika data yang akan dianalisis berskala ordinal maka perlu di transformasi terlebih dahulu menjadi skala interval agar dapat dianalisis lebih lanjut menggunakan MSI (Method Of Successive Interval).

Langkah- langkah kerja dengan menggunakan MSI (Method Of Successive Interval) sebagai berikut :

1. Perhatikan tiap butir pertanyaan dalam kuesioner

2. Untuk butir tersebut, tentukan berapa banyak orang yang menjawab skor 1,2,3,4,5 disebut dengan frekuensi.

3. Setiap frekuensi dibagi dengan banyaknya responden dan hasilnya disebut dengan proporsi

4. Tentukan proporsi kumulatif

5. Dengan menggunakan tabel distribusi normal baku, hitung nilai Ztabel untuk setiap proporsi kumulatif yang diperoleh.

6. Tentukan nilai Densitas untuk setiap nilai $\mathrm{Z}$ yang diperoleh

7. Tentukan nilai skala menggunakan rumus :

Nilai Skala NK=

8. Tentukan nilai transformasi (Y) dengan menggunakan rumus : $\mathrm{Y}=\mathrm{NS}+\mathrm{k}$

$\mathrm{K}=1+[\mathrm{NS}$ min $]$

\section{Pengujian Instrumen}

\section{a. Uji Validitas}

Validitas adalah suatu derajat ketepatan alat ukur penelitian tentang isi sebenarnya yang diukur. Analisis validitas item bertujuan untuk menguji apakah tiap butir pertanyaan benar-benar telah sah. Valididtas digolongkan menjadi tiga 
dalam kategori besar yaitu validitas isi, validitas kontruk, dan validitas eksternal. Untuk menguji apakah pertanyaan itu telah mengukur aspek yang sama digunakan validitas kontruk (Sugiyono, 2012:129). Cara mengukur validitas kontruk dengan menyusun indikator pengukuran operasional berdasarkan kerangka teori dan konsep yang akan diukur. Secara sederhana akan ditemukan validitas kontruk dengan mencari korlasi antara skor masing- masing pertanyaan dengan skor total menggunakan rumus korelasi product moment. Dari perhitungan pengujian validitas kontruk akan menghasilkan koefisien korelasi diatas 0,30. Maka dapat disimpulkan kalau data yang diperoleh tersebut valid, sedangkan koefisien korelasi yang dibawah 0,30 maka data yang diperoleh tidak valid menurut Sugiyono. (2012:183) Rumus yang digunakan sebagai berikut :

$$
\begin{aligned}
& \text { dimana : } \\
& \text { rxy = Koefisien korelasi } \\
& \mathrm{N}=\text { Jumlah responden } \\
& \mathrm{X}=\text { Skor tiap item } \\
& \mathrm{Y}=\text { Skor seluruh item }
\end{aligned}
$$

\section{b. Uji Reliabilitas}

Pengujian reliabilitas dinyatakan dengan interval consistency dengan teknik belah dua (split half), untuk keperluan tersebut makan instrumen menjadi dua kelompok, yaitu kelompok instrumen ganjil dan genap, kemudian masingmasing dijumlahkan untuk mendapatkan skor total setiap kelompok, selanjutnya skor total setiap kelompok tersebut dicairkan korelasinya yang kemudian dimasukan kedalam rumus Spearman Brown dalam buku Sugiyono (2012:130) sebagai berikut :

$$
\begin{aligned}
& r i=1+ \\
& \mathrm{ri}=\text { Reliabilitas internal seluruh instrumen } \\
& \mathrm{rb}=\text { Korelasi product moment antara belahan pertama dan kedua }
\end{aligned}
$$

Variabel yang reabel memiliki nilai diatas 0,6 dan merupaan construct yang kuat.

\section{c. Uji Normalitas}


Uji normalitas bertujuan bertujuan untuk menguji apakah sampel yang digunakan mempunyai distribusi normal atau tidak. Dalam model regresi linear asumsi ini ditunjukan oleh nilai error yang berdistribusi normal. Model regresi yang baik adalah model regresi yang dimiliki distribusi normal atau mendekati normal, sehingga layak dilakukan pengujian statistik. Pengujian normalitas data pada penelitian ini menggunakan Tes Of Normality Kolmogorov-Smirnov dalam program SPSS. Menurut Singgih Santoso (2012:293) dasar pengambilan keputusan bisa dilakukan berdasarkan probabilitas (Asymtotik Significance) yaitu. Jika probabilitas > 0,05 maka distribusi adalah normal sedangkan jika probabilitas $<0,05$ maka distribusi tidak normal.

Penelitian ini menggunakan penelitian deskriptif kuantitatif dan verifikatif sehingga masing- masing analisis dapat diuraikan sebagai berikut :

\section{Analisis Deskriptif}

Penelitian deskriptif adalah suatu metode dalam meneliti sekelompok manusia, suatu objek, suatu kondisi, suatu sistem pikiran, ataupun kelas peristiwa pada masa sekarang. Penelitian deskriptif ini adalah untuk membuat dekarya ilmiah, gambaran atau lukisan secara sistematis, faktual dan akurat mengenai fakta, sifat, serta hubungan antar fenomena yang diselidiki. Langkah dalam analisis deskriptif.

a. Setiap indikator yang dinilai oleh responden diklasifikasikan dalam lima alternatif jawaban dengan menggunakan skala ordinal yang menggambarkan peringkat jawaban.

b. Dihitung total skor dari setiap variabel (jumlah skor dari seluruh indikator variabel untuk semua responden.

c. Dihitung setiap skor variabel (Rata- rata dari total skor)

d. Untuk mendekarya ilmiahkan jawaban responden, digunakan statistik deskriptif seperti distribusi frekuensi dan tampilan dalam bentuk tabel ataupun grafik.

e. Untuk menjawab dekarya ilmiah tentang masing- masing variabel penelitian, digunakan rentang kriteria penilaian sebagai berikut : Dalam penelitian ini 
untuk menganalisis data hasil survey yang berasal dari hasil pegukuran yaitu dengan menggunakan instrumen dan skala likert dengan formulasi :

Dimana :

$\mathrm{n}=$ Jumlah Sample

$\mathrm{m}=$ Jumlah alternatif jawaban $($ Skor $=5)$

Rentang Skala (RS) sebesar :

Skala Terendah : Skor Terendah (1) X Jumlah Sample (124) $=1 \times 124=124$

Skala Tertinggi : Skor Tertinggi (5) X Jumlah Sample (124) $=5 \times 124=620$

Sehingga besarnya skala adalah : $\mathrm{RS}=(-1) \overline{(5-1)-992}$
$\mathrm{RS}=124(2)$

Prinsip pengklasifikasian presentase skor jawaban responden dengan kriteria pengklasifikasian sebagai berikut :

Tabel 3.6

\section{Analisis Rentang Skala}

\begin{tabular}{|c|l|l|l|}
\hline \multirow{2}{*}{ Rentang Skala } & \multicolumn{3}{|c|}{ Dekarya ilmiah Skor } \\
\cline { 2 - 4 } & Kompensasi & Motivasi Kerja & Kinerja \\
\hline $124-223,2$ & Sangat Tidak Baik & Sangat Tidak Baik & Sangat Tidak Baik \\
\hline $224,2-322,4$ & Tidak Baik & Tidak Baik & Tidak Baik \\
\hline $323,4-421,6$ & Cukup Baik & Cukup Baik & Cukup Baik \\
\hline $422,6-520,8$ & Baik & Baik & Baik \\
\hline $521,8-620$ & Sangat Baik & Sangat Baik & Sangat Baik \\
\hline
\end{tabular}

Sumber : Sugiyono (2012:93) disesuaikan. 
Berdasarkan hasil perhitungan diatas, maka dapat dihitung rentang skala yang selanjutnya dapat dipakai untuk memprediksi keeretan hubungan kompensasi dan motivasi kerja terhadap kinerja karyawan. Jika dituangkan dalam bentuk Bar Scale sebagai berikut :

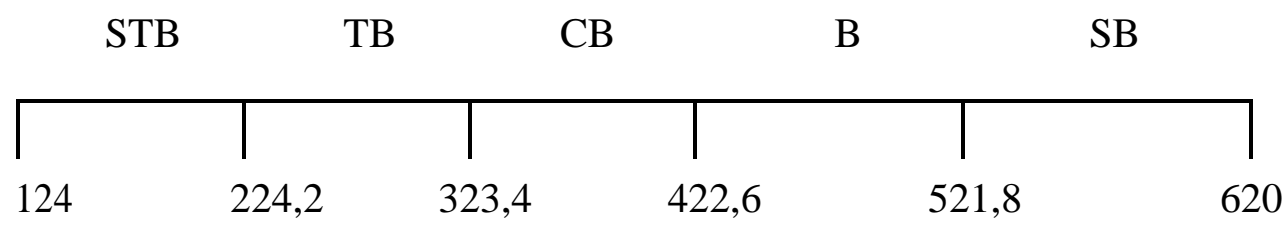

Gambar 3.2 : Bar Scale

Sumber : Sugiyono (2012:95)

Sebelum kuesioner digunakan untuk pengumpulan data yang sebenarnya, terlebih dahulu dilakukan uji coba kepada responden yang memiliki karakteristik yang sama dengan karakteristik populasi penelitian.

Uji coba dilakukan untuk mengetahui tingkat kevalidan (Validitas) dan kekonsistenan (Reliabilitas) alat ukur penelitian, sehingga diperoleh item- item pertanyaan/ pernyataan yang layak untuk digunakan sebagai alat ukur untuk pengumpulan data penelitian.

\section{Analisis Verifikatif}

Penelitian Verifikatif adalah penelitian yang pada dasarnya ingin menguji kebenaran melalui pengumpulan data di lapangan. Penelitian ini digunakan untuk menguji kebenaran dari hipotesis melalui pengumpulan data dilapangan menggunakan perhitungan statistik. Penelitian ini digunakan untuk menguji pengaruh variabel independen (X1 dan X2) terhadap variabel dependen (Y) yang diteliti. Verifikaatif berarti menguji teori dengan pengujian suatu hipotesis apakah diterima atau ditolak.

Hasil data yang telah dikonversi selanjutnya diolah menggunakan Path Analisis. Menurut Ridwan dan Engkos Achmad Kuncoro (2012:02) Path Analisis digunakan untuk menganalisis pola hubungan antar variabel dengan tujuan untuk mengetahui pengarah langsung maupun tidak langsung seperangkat variabel bebas (eksogen) terhadap variabel terikat (endogen). Adapun model analisis jalur (Analisis Path) yang digunakan pada penelitian ini adalah sebagai berikut : 
$\boldsymbol{\varepsilon}$

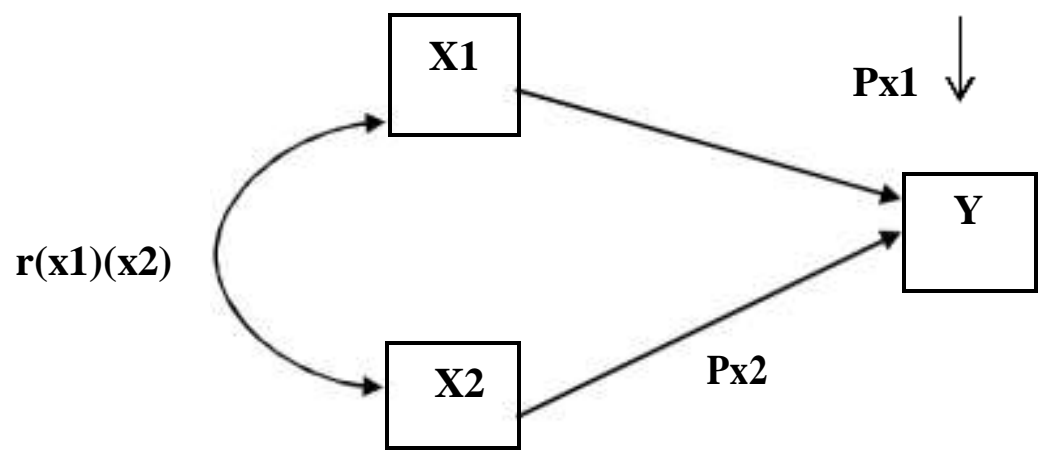

Gambar : 3.3 Jenis Umum Model Path Analysis

Sumber : Riduan (2012:3)

\subsubsection{Uji Hipotesis}

Pengujian tiga hipotesis yang digunakan pada penelitian ini adalah sebagai berikut

1. Korelasi antara X1 dan X2 (Uji t)

Ho : $\mathrm{p} \times 2 \times 1=0$

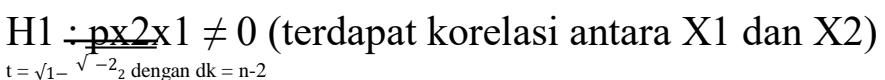

2. Pengaruh parsial dari $\mathrm{X} 1$ dan $\mathrm{X} 2$ terhadap $\mathrm{Y}$ (Uji t)

Ho : pyx $1, \operatorname{pyx} 2=0$

H1 : pyx 1, pyx $2 \neq 0$ (terdapat pengaruh parsial dari

$\mathrm{X} 1$ dan X2 terhadap $\mathrm{Y}$ )

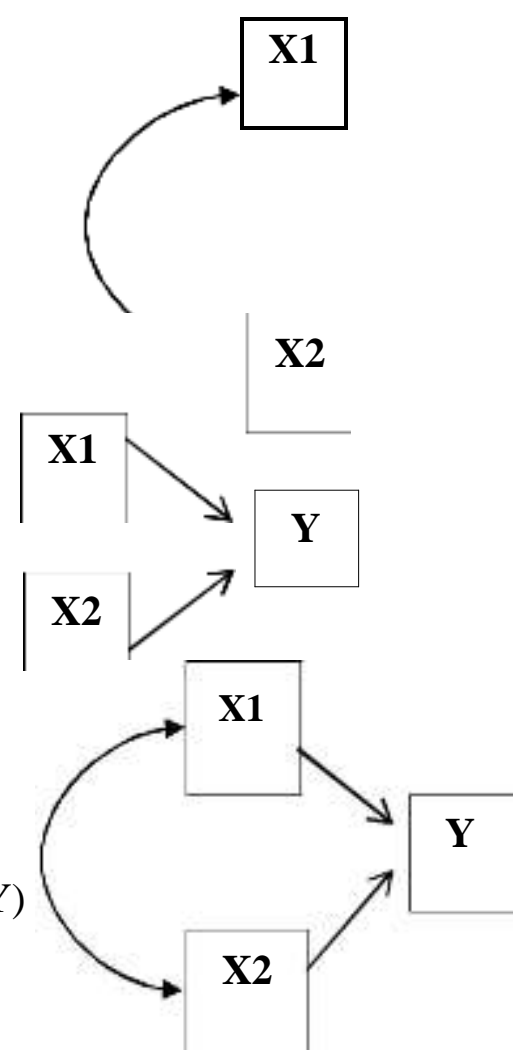


Sehubungan dengan yang telah dijelaskan gambar diatas, maka hipotesis dalam penelitian ini sebagai berikut :

1. Terdapat hubungan yang signifikan antara kompensasi dengan motivasi kerja karyawan PT Pupuk Di Karawang

2. Terdapat pengaruh parsial yang signifikan antara kompensasi dan motivasi kerja terhadap kinerja karyawan PT Pupuk Di Karawang

3. Terdapat pengaruh simultan yang signifikan antara kompensasi dan motivasi kerja terhadap kinerja karyawan PT Pupuk Di Karawang.

\section{HASIL DAN PEMBAHASAN}

Data yang dikumpulkan pada penelitian ini yaitu berupa data yang diperoleh dari penyebaran kuesioner, yang ditujukan kepada karyawan pada bagian Gedung Pusat Administrasi PT Pupuk Di Karawang. Penyebaran kuesioner ditujukan kepada 124 responden yang disebarkan pada setiap unit diantaranya departemen humas, departemen keuangan, departemen sdm, departemen akuntansi, departemen anggaran, departemen pengembangan, departemen pengadaan, departemen TI, departemen tata kelola perusahaan, departemen manajemen resiko, departemen hukum administrasi perkantoran dan departemen TU. Dengan karakterisitik responden sebagai berikut :

A. Karakteristik responden menurut jabatan pekerjaan

Menunjukan bahwa responden mayoritas adalah yang memiliki jabatan Staff yaitu sebesar $68 \%$ atau sebanyak 84 responden dari 124 responden.

B. Karakteristik responden menurut usia

Menunjukan bahwa responden di dominasi oleh karyawan yang berusia sekitar lebih dari 30 tahun yaitu sebesar 53\% atau sebanyak 66 responden dari 124 responden. 
C. Karakteristik Responden menurut Jenis Kelamin

Menunjukan bahwa responden di dominasi oleh karyawan yang berjenis kelamin laki- laki yaitu sebesar $61 \%$ atau sebanyak 76 responden dari 124 responden.

D. Karakteristik Responden menurut Tingkat Pendidikan

Sebagain besar responden memiliki latar belakang lulusan sarjana strata satu (SI) yaitu sebesar 46\% atau sebanyak 57 responden dari 124 responden.

E. Karakteristik Responden menurut Lama Bekerja

Menunjukan bahwa sebagian besar masa kerja responden 5- 10 tahun yaitu sebesar 39\% atau sebanyak 49 responden dari 124 responden.

F. Karakteristik Responden menurut Kompensasi

Menunjukan bahwa mayoritas responden mendapatkan kompensasi sesuai dengan normatif yaitu sebesar 85\% atau sebanyak 105 responden dari 124 responden.

Selain itu, menunjukan bahwa variabel kinerja berada pada garis skala 508 dengan kriteria baik. Dengan demikian dapat dikatakan responden menilai baik pada variabel kinerja di PT Pupuk Di Karawang.

Adapun pembahsan dari metode deskriptif mengenai masing-masing variabel dalam penelitian ini dapat diuraikan sebagai berikut :

\section{Kompensasi (X1)}

Kompensasi pada PT Pupuk Di Karawang memiliki total skor dari 7 indikator sebesar 3.458 dengan rata-rata skor sebesar 494 yang berada pada rentang skala 494-521,8 Dengan kriteria baik, artinya kompensasi di PT Pupuk Di Karawang dinilai baik oleh karyawan dengan melihat dari 7 indikator gaji, bonus, insentif, asuransi, tunjangan, program rekreasi, dan fasilitas memiliki kriteria baik.

2. Motivasi Kerja (X2) 
Motivasi Kerja pada PT Pupuk Di Karawang memiliki total skor dari 11 indikator sebesar 5.504 dengan rata-rata skor sebesar 500 yang berada pada rentang skala 500-521,8 Dengan kriteria baik, artinya kompensasi di PT Pupuk Di Karawang dinilai baik oleh karyawan dengan melihat dari 11 indikator terdapat 10 indikator memiliki kriteria baik yaitu semangat untuk lebih unggul, tanggung jawab, menyukai tantangan dalam bekerja, berani beresiko, kreatif dan inovatif, pencapaian prestasi, penghormatan, suka mempengaruhi, suka bekerja sama dan berhubungan baik dengan organisasi. Sedangkan terdapat 1 indikator yang memiliki kriteria sangat baik yaitu mampu menjadi teladan.

\section{Kinerja (Y)}

Kinerja Karyawan pada PT Pupuk Di Karawang memiliki total skor dari 10 indikator sebesar 5.087 dengan rata-rata skor sebesar 508 yang berada pada rentang skala 508-521,8 Dengan kriteria baik, Sehingga dapat disimpulkan secara umum bahwa kinerja karyawan di PT. Pupuk Kujang dinilai baik oleh karyawan dengan melihat dari 10 indikator terdapat 8 indikator yang memiliki kriteria baik yaitu kemampuan, keterampilan, hasil kerja, pencapaian target, jalinan kerja, kekompakan dan pengambilan keputusan. Sedangkan terdapat 2 indikator yang memiliki kriteria sangat baik yaitu tanggung jawab dalam tugas dan kemandirian.

\subsubsection{Pembahsan Verifikatif}

Adapun pembahsan dari metode verifikatif dalam penelitian ini dapat diuraikan sebagai berikut :

1. Hubungan kompensasi dengan motivasi kerja memiliki nilaikoefisien korelasi sebesar 0,462 dan mempunyai hubungan yang sedang.

2. Pengaruh parsial kompensasi dengan motivasi kerja terhadap kinerja karyawan.

a. Pengaruh parsial kompensasi (X1) terhadap kinerja karyawan (Y) memiliki nilai sebesar 0,541 .

b. Pengaruh parsial motivasi kerja (X2) terhadap kinerja karyawan (Y) memiliki nilai sebesar 0,094 .

3. Pengaruh simultan antara variabel kompensasi dan motivasi kerja terhadap kinerja dengan kriteria uji sig $(0,000)<\alpha(0,05)$ dan fhitung $(105,262)>$ ftabel 
$(3,07)$ artinya $\mathrm{H} 0$ ditolak total pengaruh $\mathrm{X}$ dan $\mathrm{X} 2$ terhadap $\mathrm{Y}$ sebesar 0,635 atau $63,5 \%$ hal ini menunjukan bahwa X1 dan X2 memiliki kontribusi terhadap Y sebesar 63,5\% sedangkan sisanya 0,367 atau 36,7\% merupakan kontribusi variabel lain $(\varepsilon)$ yang tidak diteliti.

\section{KESIMPULAN DAN SARAN}

\section{Kesimpulan}

Berdasarkan hasil Penelitian dan pembahasan hasil analisis mengenai pengaruh kompensasi dan motivasi kerja terhadap kinerja karyawan pada PT Pupuk Di Karawang, maka beberapa hal yang bisa penulis jadikan kesimpulan dari hasil penelitian sebagai berikut :

1. Kompensasi pada PT Pupuk Di Karawang memiliki total skor dari 7 indikator sebesar 3.458 dengan skor sebesar 494 yang berada pada rentang skala 494-521,8 Dengan kriteria baik, Sehingga dapat disimpulkan secara umum bahwa responden menilai baik terhadap pertanyaan yang diungkap dalam kuesioner mengenai kompensasi pada PT Pupuk Di Karawang.

2. Motivasi Kerja pada PT Pupuk Di Karawang memiliki total skor dari 11 indikator sebesar 5.504 dengan skor sebesar 500 yang berada pada rentang skala 500-521,8 Dengan kriteria baik, Sehingga dapat disimpulkan secara umum bahwa responden menilai baik terhadap pertanyaan yang diungkap dalam kuesioner mengenai motivasi kerja pada PT Pupuk Di Karawang.

3. Kinerja Karyawan pada PT Pupuk Di Karawang memiliki total skor dari 10 indikator sebesar 5.087 dengan skor sebesar 508 yang berada pada rentang skala 508-521,8 Dengan kriteria baik, Sehingga dapat disimpulkan secara umum bahwa responden menilai baik terhadap pertanyaan yang diungkap dalam kuesioner mengenai kinerja karyawan pada PT Pupuk Di Karawang.Hubungan diantara variabel bebas yaitu antara kompensasi (X1) dan motivasi kerja (X2) menunjukan korelasi sebesar 0,462 hal ini menunjukan bahwa kompensasi (X1) dan motivasi kerja (X2) mempunyai hubungan yang sedang. Hubungan diantara variabel bebas yaitu antara kompensasi (X1) dan motivasi kerja (X2) menunjukan korelasi sebesar 
0,462 hal ini menunjukan bahwa kompensasi (X1) dan motivasi kerja (X2) mempunyai hubungan yang sedang.

4. a) Pengaruh kompensasi (X1) secara parsial terhadap kinerja (Y) adalah sebesar 0,541 atau 54,1\%. b) Pengaruh motivasi kerja (X2) secara parsial terhadap kinerja (Y) adalah 0,094 atau 09,4\%. Karena 54,1\% lebih besar dari $09,4 \%$, maka dapat dinyatakan bahwa kompensasi (X2) lebih banyak memberikan kontribusi terhadap kinerja karyawan dibandingkan dengan motivasi kerja (X2).

5. Terdapat pengaruh kompensasi (X1) dan motivasi kerja (X2) secara simultan terhadap kinerja karyawan(Y) dengan kriteria uji sig $(0,000)<$ $\alpha(0,05)$ dan f hitung (105.262)> f tabel (3.07) dan total pengaruh kompensasi (X1) dan motivasi kerja (X2) terhadap kinerja karyawan (Y) sebesar 0,635 dengan demikian dapat disimpulkan bahwa kompensasi (X1) dan motivasi kerja (X2) memiliki pengaruh terhadap kinerja karyawan (Y) sebesar 0,635 atau $63,5 \%$ sedangkan sisanya 0,365 atau $36,5 \%$ merupakan kontribusi variabel lain $(\varepsilon)$ yang tidak diteliti.

\section{Saran}

Berdasarkan hasil penelitian yang dialkukan, maka penulis memberikan beberapa saran yang dapat dikemukakan dalam penelitian ini adalah sebagai berikut :

1. PT Pupuk Di Karawang diharapkan dapat meningkatkan kompensasi yang diberikan, didukung dengan pemberian kompensasi yang baik dan sesuai kepada karyawan untuk menjadi acuan karyawan dalam meningkatkan dan memaksimalkan kinerja dengan stabil.

2. PT Pupuk Di Karawang diharapkan dapat meningkatkan motivasi kerja pada karyawan, dengan meningkatnya motivasi kerja karyawan maka akan mendorong dan menumbuhkan semangat kerja sehingga akan timbul keinginan dalam diri untuk lebih meningkatkan kinerja yang terbaik dan maksimal.

3. PT Pupuk Di Karawang diharapkan dapat meningkatkan kinerja karyawan dengan memperhatikan faktor apa yang meningkatkan kinerja, dengan 
adanya perhatian perusahaan kepada karyawan maka karyawan merasa diakui sehingga karyawan akan memberikan kinerja yang terbaik bagi perusahaan.

4. Terdapat korelasi dengan nilai Koefisien korelasi sebesar 0,462 dan mempunyai tingkat hubungan yang sedang dan nilainya positif oleh karena itu kompensasi dan motivasi kerja yang telah diberikan oleh perusahaan harus sangat ditingkatkan lagi karena kedua faktor tersebut memiliki pengaruh dalam peningkatan kinerja karyawan pada perusahaan.

5. Terdapat pengaruh dan variabel kompensasi lebih banyak memberikan kontribusi terhadap kinerja karyawan dibandingkan dengan variabel motivasi kerja. Agar kinerja karyawan tetap berjalan baik, maka perusahaan harus mengetahui dimensi dalam kompensasi yng sedang dibutuhkan karyawan serta mempertahankan dan meningkatkan motivasi kerja yang sudah ada sehingga dapat meningkatkan kinerja karyawan.

6. Pengaruh simultan memiliki kontribusi sebesar $63,5 \%$ sedangkan sisanya 36,7\% merupakan kontribusi variabel lain yang tidak diteliti, maka untuk penelitian selanjutnya disarankan untuk memperluas penelitian dengan cara menambah variabel penelitian agar perusahaan dapat menetapkan kebijakan yang lebih efektif bagi peningkatan kinerja karyawan.

\section{DAFTAR PUSTAKA}

Sedarmayanti. 2017. Perencanaan dan Pengembangan SDM Untuk Meningkatkan Kompetensi Kinerja dan Produktivitas Kerja. Bandung : Refika Aditama

Hamali, AY. 2017. Pemahaman Manajemen Sumber Daya Manusia-Strategi mengelola Karyawan. Jakarta : Caps Publishing

Sutrisno, E. 2016. Manajemen Sumber Daya Manusia. Jakarta : Kencana Prenandamedia Group

Amir, MF. 2015. Memahami Evaluasi Kinerja Karyawan. Jakarta : Mitra Wacana Media

Wijayanto, D. 2012. Pengantar Manajemen. Jakarta : Gramedia Pustaka Utama 
Pranadita, N. 2018. Perumusan Strategi Perusahaan. Yogyakarta :Deepublish

Sudaryono, Ariwibowo, Sofianti. 2018. Manajemen Sumber Daya Manusia-

Kompensasi Tidak Langsung dan Lingkungan Kerja Fisik. Jakarta : Penerbit Andi

Marjuni, S. 2015. Buku Ajar Manajemen Sumber Daya Manusia. Makasar : CV.

Sah Media

Suryani, NK, Jhon. 2018. Kinerja Organisasi. Yogyakarta : Deepublish

Sugiyono, 2013. Metode Penelitian Pendidikan. Bandung : Alfabeta

Undang-undang No 13 Tahun 2003 (Tentang Ketenagakerjaan, melalui Keputusan Nomor 2000-07/2003)

Laporan Tahunan PT Pupuk Di Karawang https://www.pupuk-

kujang.co.id/publikasi/annual-report/254-annual-sustainability-report-2017

Diakses tanggal 10 Januari 2019.

Yuli Suwati (2013). Pengaruh Kompensasi dan Motivasi Kerja terhadap Kinerja Karyawan pada PT. Tunas Hijau Samarinda, ejurnal.adbisnis.fisip-unmul.ac.id .Diakses tanggal 19 Januari 2019. 
Tanto Wijaya, Fransisca Andreani. (2015). Pengaruh Motivasi Kerja dan Kompensasi terhadap Kinerja Karyawan pada PT. Sinar Jaya Abadi Bersama, https://media.neliti.com. Diakses tanggal 3 Januari 2019.

Sugiannor. (2014). Pengaruh Kompensasi dan Motivasi terhadap Kinerja Karyawan bagian Pemasaran PT. Coca Cola Distribution Indonesia Salles Office Banjarbaru, sia.stiepancasetia.ac.id. Diakses tanggal 3 Januari 2019.

Agil, Susilaningsih, Sri Muryati. (2013). Pengaruh Kompensasi dan Motivasi Kerja terhadap Kinerja Karyawan Perusahaan Daerah Air Minum (PDAM) Surakarta, jurnal.fkip.uns.ac.id. Diakses 5 Februari 2019.

Elisabeth Victoria, Sajangbati. (2016). Pengaruh Kompensasi, Pengembangan Karir dan Motivasi terhadap Kinerja Karyawan PT. Bank Negara Indonesia (Tbk) Kantor Wilayah Manado, https://ejournal.unsrat.ac.id Diakses tanggal 5 Januari 2019.

Billy Taufiq Hermawan. (2008). Hubungan Kompensasi dengan Motivasi Kerja Karyawan Pada Dispenda Kabupaten Ciamis, https://repository.widyatama.ac.id Diakses tanggal 16 Agustus 2019. 